\title{
THE CHURCH AND COMMUNITY LIFE IN EARLY MIDDLEBURG HISTORY
}

\author{
by Professor Gary H. Koerselman \\ Sioux City, lowa
}

Professor Koerselman is a native of Sioux City, Iowa and received his $B$. A. from Northwestern College in Orange City which explains his interest in the area about which he writes. In 1965 Professor Koerselman received his M. A. from the University of South Dakota, Vermillion, and he will receive his Ph. D. from Northern Illinois University in June of this year.

The story of Middleburg is unique in the annals of Iowa History. This once-flourishing community developed from the establishment of a small church rather than from such typical institutions as city government, grain elevators, railroads, banking companies, and general stores. The church was founded in 1885 near the then beautiful Bell's Lake in the middle of Sioux County.

The pioneers, who had settled in the region during the seventies, shared a common Dutch heritage. They composed part of the "second great immigration" from Holland-the first being that of the seventeenth century to New York. Once again, disenchanted Dutchmen had deemed it necessary to escape from the social strains of Holland to the promised land of America. The fertile lands of Holland, Michigan, Pella, Iowa, and finally northwestern Iowa provided an attractive alternative. ${ }^{1}$

Before the church, the Dutch in the vicinity of Bell's Lake remained fragmented, their loyalties directed toward the surrounding communities of Sioux Center, Orange City, Hull, Boyden, and Hospers. ${ }^{2}$ During the harsh winter of 1884-5, however, Dutch Reformed leaders in Sioux Center and Orange City became concerned about the frequent inability of their Christian brothers from Bell's Lake to attend church services. They commissioned the Reverend Seine Bolks, a talented circuit rider, and. specialist in organizing new congregations for the Reformed Church of America, to examine the possibilities of a new church. On the sweltering evening of July 31, 1885, Bolks, a Reformed Church extension committee, and 1.5 recep- 
tive farmers gathered in the schoolhouse one mile south of Bell's Lake to organize the Free Grace Reformed Church. ${ }^{3}$

William Davidson, a land agent and banker from nearby Pattersonville (later Hull), donated five acres of prime land upon which the new congregation constructed a church 40 feet in length, 24 feet in width, and 14 feet high. The clever $\mathrm{Mr}$. Davidson provided the initial building funds at ten percent interest. At first the congregation associated with the Pattersonville Reformed Church, which had been organized at the same time. They employed the Reverend Anthony Zwemer at a yearly salary of $\$ 700 .{ }^{4}$

Under the enthusiastic leadership of Zwemer, the membership of the church expanded to 100 families by 1900 . This made it necessary to enlarge the original church structure, to construct three horsebarns, and to build an expensive parsonage designed to attract a pastor with a large family. Also, in 1899 a Christian Reformed Church was established and boasted a membership of 50 families by $1902 .{ }^{5}$

As the churches expanded, a village arose. First it was just the parsonage. Then, in 1892 Roel DeJong established a general store and organized a weekly grocery route throughout the territory. In the next few years a machinery store, a blacksmith and harness shop, a second general store, and a tiny shoe repair shop appeared on the scene. By 1900 the population, including immigrant farm hands, reached approximately 100. In the absence of official incorporation, the village became known simply as Middleburg, signifying its location in the middle of the county and in between the larger surrounding towns. ${ }^{\circ}$

The church continued to be the unifying force in the community. The Sabbath Day worship services easily developed into the central community activity. Preparation for the Sabbath began on Saturday with special Bible reading and family meditation after the noon meal. On Saturday afternoon the women prepared extra food and men performed as many chores as posible to reduce the Sabbath work load. Promptly at 6:00 on Saturday evening, Jan Levering, the church's first janitor, tolled the huge steeple bell, donated by the first elder, Gerrit Leusink. The awe-inspiring echo of the bell throughout the countryside reminded the people of the approaching Sab- 
bath and the need to polish shoes, fix hair, take baths, and prepare Sunday School lessons.

The entire family arose early on Sunday morning. An aura of excitement, stemming more from the anticipation of fellowship than the expectation of a long sermon, accompanied its activities. As the family entered the churchyard, the women were whisped inside and seated to the left of the pulpit. After tying the horses in the family stall, rented from the church for $\$ 3.00$ annually, the men found places on the right side of the sanctuary which was provided with spitoons for the tobacco chewers. Two front benches were reserved for the ruling body of elders and deacons (consistory) which customarily met with the pastor shortly before the services. At half past nine Jan Levering, who lived in one of the horsebarns as part payment for his services, rang the bell signaling the beginning of the service. This was followed with a prelude, played on a fine organ donated by the second elder, Jurgen Dykstra. Five minutes later the consistory, led by the minister, marched solemnly into the sanctuary and the service was continued with the singing of Dutch psalms. ${ }^{7}$

The morning service was followed by a light lunch featuring homemade soup and bread. After an hour of fellowship the congregation gathered for a second worship service. The hour long sermon, delivered in the Dutch language, was ostensibly the most important element of the service. The morning sermon dealt with doctrinal questions while the afternoon sermon stressed evangelism. Sometimes the minister admonished members of the congregation from the pulpit, but the more serious sins against the moral codes of the church had to be brought before the consistory which could bar guilty members from the communion table until they had reconciled themselves with God.

As the official leader of the congregation and president of the consistory, the minister, known to most as "Dominie," became the central figure in the community. The significant events in the normal life of the people-baptism, marriage, and funerals-were all presided over by the minister, and required elaborate church ceremonies. The people looked up to the minister as the moral leader of the community. 
In spite of the spiritual nature of the ministry, parishioners consistently consulted with the pastor concerning a much wider range of issues. They believed that the minister's advanced education made him wiser and more knowledgable in all areas. To conduct a successful pastorate in Middleburg, the minister had to possess some expertise not only in theology, but economics, politics, science, and psychology. Serious neighborhood disputes often ended in his study. Occassionally he even treated ailing farm animals.

The minister was expected to speak his mind on social issues which affected the life of the congregation. Rev. Bolk's vehement attack on the fraternal principles of the Grange completely stifled its membership drive in the area. Rev. Zwemer's protests against the political demands of the Populists kept Middleburg safe for Republicanism. Rev. Koster's warnings against dealing with certain notorious Sioux City peddlers and "outside" horse traders protected the congregation from extortion.

The official practice of huisbezoek (house visitation) presented ministers with an opportunity to influence the private lives of the parishioners. Once a year the minister and an elder visited each household to see that its spiritual life was in order. This was commonly regarded as a serious matter. The fear of having to answer to the minister during huisbezoek was in itself a controlling factor in the moral conduct of the community. Parents employed the threat of exposure during huisbezoek in disciplining their children.

The Reverend Herman Douwstra, who served the congregation from 1903 to 1921, probably became the most venerated clergyman in Middleburg's history. Known affectionately as "Old Dominie Douwstra," he developed the techniques of "country preaching" to their fullest. The forceful Douwstra spearheaded the drive to build a new church structure in 1909, helped establish a Christian school in Middleburg, and refurbished the catechism program. ${ }^{8}$ His inordinate popularity, however, animated from his capacity to "get on" with the people. His personableness, his ability to communicate with the people and empathize with their concerns won him a distinguished position at the penacle of Middleburg society. This position was strengthened by his ability to exercise crucial 
leadership in times of trouble, especially family trouble. It was Dominie Douwstra who successfully pleaded the insanity of a young man belonging to a leading family, who, in a fit of rage, had killed his beautiful wife. Later it was Dominie Douwstra who convinced the son of another leading family to bear the responsibility for his illegitimate child. On still another occasion, it was Dominie Douwstra who agreed to serve as probation officer for a group of adventurous boys apprehended for stealing chickens.

In May of 1921, the graying and slightly stooped, but still alert Douwstra decided to resign his pastorate because of the deteriorating health of his wife. On the last Sunday of June, people came from miles around to hear his eloquent farewell sermon and to get a final glimpse of the man who had long dominated community life. The somber expressions and quiet sobs made this one of the saddest days in Middleburg's history.

Even before Douwstra's retirement, the Sunday School program had become the central element in the growing role of the church in the community. When the program had been introduced in 1892, many objected on the grounds that it might interfere with the importance of the regular church services as well as the "after church" coffee hour. Once established, however, the Sunday School grew rapidly. By 1900 special classes were provided for every age group. Some more enthusiastic members even organized an adult class taught by the minister. ${ }^{9}$

The elders and deacons customarily served as teachers. Elder Frans Gunnink, the first permanent secretary of the consistory, taught the unmarried young men's class, and became the most distinguished teacher. His skillful manner of relating his broad Biblical knowledge to the ordinary situations of daily life, and his arduous advocation of high personal moral standards made him the most influential figure in the lives of many young men. Younger boys anxiously anticipated "moving-up" to Gunnink's class. The Sunday School program provided the most significant learning experience for many youngsters who had left the public schools prematurely to assist the family with the farm work. 
The Sunday School picnic and Christmas program were central activities in the church. The annual Christmas Eve program began with excited children marching into the church sanctuary bearing lit candles and singing carols. The Sunday School Superintendent read the Christmas story from the scriptures. Each class then presented carefully rehearsed skits, dialogues and carols. Awards were presented to youngsters who had accomplished a perfect attendance during the year. Everyone received a sack of Roel DeJong's candy which included a rare orange. This proved a satisfactory substitute for Santa Claus who never visited the homes of the stern Dutchmen.

Community spirit was further sustained by the Sunday School picnic which was held the first week in September after the oat harvest and before cornpicking. At first the picnic was held in Jake Vander Zwaag's farm grove. In 1899 one of the county newspapers reported 40 horse-drawn vehicles and over 300 people in the picnic area. ${ }^{10}$ In 1900 the picnic was transferred to the churchyard. The day began with devotion and psalms and activities for every age group followed. Children ran races, played drop-the-handkerchief, and hideand-go-seek. The afternoon softball game which pitted the married against the unmarried men became the pivotal event in the day's activities. The older men usually pitched horseshoe in the shade and told tales of the early prairie days while the ladies exchanged niceties and caught up with the latest "happenings." Indeed these activities enhanced a feeling of belongingness necesary to bind the community together.

The success of the Sunday School led to the establishment of additional programs. The Women's Mission, and Aid Society, established in 1894 to promote "good work both at home and abroad, for the benefit of God's kingdom," provided a small band of ladies with an opportunity for service and fellowship. The society met in the parsonage during the Sunday School hour every other week. ${ }^{11}$ Some husbands discouraged attendance fearing it might interfere with the proper "place" of women in the family and the community.

The church's fundamental concern for its youth was reflected in the many programs established for young people. In 1905 Rev. Douwstra persuaded the consistory to authorize a 
Girls' Society dedicated to preparing women for the religious rigors of marriage. This led to the establishment of a Christian Endeavor which met every Sunday evening. The Endeavor was designed to prepare young people for "future" church leadership. Also, under the careful supervision of Rev. Douwstra, the church established a singing school to teach youngsters the Dutch psalms. The youngsters successfully pressed for the study of a wider variety of music, even secular music. ${ }^{12}$

Partly as a result of their training in singing school, about 25 young men, under the astute leadership of a local merchant named Daniel C. Duncan, organized a Middleburg band in 1906. At a time when such groups were extremely popular, Duncan's band excelled. Its preeminent reputation insured its presence at every major celebration in the county.

The band's popularity helped attract a thousand people to the Fourth of July celebration in Middleburg in 1912. The arrangements for the event were handled through various church committees. The general tone of the celebration clearly illustrated the agrarian mentality of this small isolated community. The crude homemade entries in the afternoon parade often depicted big city corruption which Middleburgers obviously misunderstood. Twelve year old Jake Dykstra entered a float portraying a city "bandit" under the surveillance of a policeman. But, when the bandit subtly presented a bottle of whisky, the policeman immediately laid down his club and gleefully emptied the bottle while the bandit escaped. That evening Rev. Douwstra delivered a patriotic address in which he thoughtfully reminded his fellow Dutchmen that patriotism was important, but the love of God must come before the love of country. Indeed, the love of God had brought their forefathers from the land of Holland to the peaceful plains of Iowa. The address was followed by a band concert and fireworks. Jan Levering moved methodically through the audience collecting a nickel from each farmer to pay for the fireworks.

The better side of human nature was often displayed on such occasions. On this particular evening a horse belonging to an immigrant farm hand died of over exhaustion. Knowing that the unfortunate man would perish without a new horse, elders Harm Vander Maten and Gerrit Vander Wilt organized 
a fund-raising drive which collected enough to purchase a team. The incident was illustrative of how the Dutch could display a paternalistic attitude toward the recent immigrants. Yet, they could simultaneously display unwarranted self-righteousness when they unmercifully chastised the immigrants for a lack of familiarity with American ways. This demonstrated the major dilemma facing the Dutch in America. On the one hand Middleburgers clung tenaciously to their Dutch heritage while, on the other hand, they felt great pride in being American citizens. ${ }^{13}$

In spite of this dilemma the Dutch in Middleburg felt a special obligation to their fellow nationals, both at home and abroad. The offering plate was often circulated during the last psalm of the Sunday afternoon service for victims of natural disasters in the vicinity. In 1894, for example, the congregation collected almost $\$ 100$ to help the disaster-stricken families around Sioux Center who had lost their homes in a cyclone.

Middleburgers also felt a special obligation toward their fellow nationals outside of the immediate community. This obligation was bolstered by the long accounts of events in the "old country" published weekly in such local newspapers as De Volksoriend and the Sioux County Herald. The Dutch intently supported the South African Boers in their futile struggle against the English imperialists. Meanwhile, they anxiously embraced the flamboyant Theodore Roosevelt as one of their own.

The congregation was not without its differences, of course. Differences arose concerning church policy and organizational procedures. These involved the normal amount of personality conflict. In earlier years members often bickered about defining a realistic tithing policy. They squabbled over selecting procedures for electing consistory members. The congregation split over the question of uniting with the German Reformed denomination. The qualifications for church membership and baptism became difficult issues to resolve. The alleged horse-trading and other sordid business activities of one pastor divided the loyalties of the congregation for a time. Prior to World War I, however, the church leadership 
resourcefully mollified such differences in hopes of establishing a permanent community in the Iowa wilderness.

The demise of the church as the catalyst which bound the Middleburg community together began during World War I. The intense wartime propaganda abruptly turned the attention of the people toward nationalistic issues. Dutch concerns now became American concerns as they learned to hate the Hun, wave the American flag, and suspiciously watch for Bolsheviks and socialists who were reputed to be undermining the country from within. In 1918 when the German-born Christian Reformed Minister, Jonathan H. Beld, delayed his appearance at the ceremony honoring American victory in war, there was some ominous talk of hanging him on the recently constructed flag pole in front of the church.

The twenties ushered in a number of technological advancements which began to transform the community into one composed of mechanized commercial farms. The introduction of tractors, larger machinery, and electricity slowly negated the need for horses and hired hands. The automobile, the radio, and the telephone forced the issues of a larger American community upon the Middleburgers, thus thrusting them out of their serene provincialism.

The depression-ridden thirties resulted in a New Deal federal land policy which discriminated against smaller firms, and national welfare programs which substituted the distant Washington bureaucracy for the church as the central binding force in the comunity. By 1970, an empty store, a small clump of houses, and one remaining church-only half full on Sunday-all testified to how the pressures of the twentieth century had transformed the once flourishing, distinctly Dutch community into just another configuration of modern farms. Yet, buried in its memorable past is a unique and unforgetable phase of American history.

\section{Notes}

${ }^{1} \mathrm{Jacob}$ Van Der Zee, The Hollanders in Iowa (lowa City, Iowa, 1912), p. 138; Henry S. Lucas, Netherlands in America (Ann Arbor, Michigan, 1955), p. 635; Nelson Nieuwenhuis, A History of the Dutch Settlement in South Dakota to 1900, Unpublished M. A. Thesis, University of South Dakota, Vermillion, 1948, pp. 5-8. 
${ }^{2}$ Atlas of Sioux County, Iowa, Section II, p. 9; The Sioux County Herald, November 19, 1874.

${ }^{3}$ Minutes of the Consistory Meetings, Free Grace Reformed Church, Middleburg, Iowa (1885-1923).

${ }^{4}$ Unless otherwise designated, the basic source material for this article was provided in oral interviews with the following individuals: Henry De Groot, Mrs. Elizabeth De Leeuw, Jake Dykstra, William Kalsbeek, Ben Vander Griend, Frank Vander Wilt, and Gardie, John, and Sam Wiersma of Orange City, Iowa; Gerrit Franken, Reverend John Roggen, Gerrit Koerselman, and Herman Vander Maten of Sioux Center, Iowa; Henry Wissink of Boyden, Iowa; and, Jake De Zeeuw and Henry Koerselman of Hull, Iowa.

${ }^{5}$ Minutes of the Christian Reformed Church, Middleburg, Iowa.

${ }^{8}$ United States Census Report, 1900, Government Printing Office, Washington, D.C., Vol. I, Part I, Population, p. 158.

${ }^{7}$ Seventy-fifth Anniversary Bulletin, Free Grace Reformed Church, Middleburg, Iowa (1960).

${ }^{8}$ Minutes of the Building Committee, Free Grace Reformed Church, Middleburg, Iowa (1907).

${ }^{9}$ The Annual Sunday School Report, (1910), Free Grace Reformed Church, Middleburg, Iowa.

${ }^{10}$ De Volksvriend, September 5, 1899.

${ }^{11}$ Minutes of the Ladies Mission Society, Free Grace Reformed Church, Middleburg, Iowa (1924).

${ }^{12}$ Minutes of the Christian Endeavor (1923), Free Grace Reformed Church, Middleburg, Iowa.

${ }^{13}$ Record of the Vander Maten Family, B. D. Dykstra \& Sons, Orange City, Iowa (1940).

\section{INDEX TO VOLUME 40}

For research and collection purposes, a complete and comprehensive Index file of all ANNALS' issues, dating from Oct. 1893 to the present, is kept in the ANNALS office. The public is invited to make use of this facility.

"A Diary of Prison Life In Southern Prisons," by Amos W. Ames, 1-19

"A New Day of Hope: Iowa Commission for the Blind," 161-170

"A Revolution In Iowa: The Corn Picker," 220-221

"A Study In Border Confrontation: The Iowa-Missouri Boundary Dispute," by Carroll J. Kraus, 81-107

"A Town That Disappeared: Jeddo, Iowa," by Gloria Martin, 56-61

Abels, Leonard, "From Westminster To Des Moines," 24-55

Act to Regulate Blacks \& Mullattoes, A Code passed by Iowa Legislature, $343-376$

Aero engine, Roberts 2 Cycle, 338-391

Airline-world's first scheduled, 338-391 
Copyright of Annals of Iowa is the property of State of Iowa, by \& through the State Historical Society of Iowa and its content may not be copied or emailed to multiple sites or posted to a listserv without the copyright holder's express written permission. However, users may print, download, or email articles for individual use. 